doi:10.7592/MT2005.31.ylojaht

\title{
Jahist tšuktšide juures
}

Ülo Siimets

\begin{abstract}
Teesid
Artikkel annab ülevaate 1971. aastal Tšukotkal tšuktside seas kasutatud jahipidamisviisidest ja -vahenditest. Võrdluseks esitatakse kirjeldusi varasemast jahikultuurist. Rannaäärsed tšuktšid tegelevad põhiliselt mereloomade küttimisega. Talvel püütakse ka jäneseid, rebaseid, polaarrebaseid, ahme, hunte ja vahel ka jääkarusid. Karjakasvatajad-tšuktšid elavad sisemaal. Nende jahiloomad on põhjapõdrad, lumelambad, pruunkarud, harva ka jääkarud ning muidugi jänesed, rebased, hundid, ahmid. Jahindusele spetsialiseerunud tšuktšid püüavad lisaks harilikku oravat, metsnugist ja soobleid. Jahipidamise juurde kuulusid tookord vastavad riitused, näiteks karupeied ja kurjade vaimude peletamine.
\end{abstract}

Märksõnad: hanejaht, jaht, karujaht, põdrajaht, tšuktšid, Tšukotka, tundra

Viibisin alates 1971. aasta jaanuarist kümme kuud Magadani oblastis Tšukotka poolsaarel Anadõri tundras. Tšuktšid kutsusid mind Jeloks, sest tšuktši keeles ei ole ü-tähte. Jelo tähendab tšuktši keeles 'sõber'. Sellest käigust kujunes tšuktšide elulaadi osalusvaatlus.

Tšuktšidest teadsin enne seda väga vähe. Eesti entsüklopeedia ei olnud selleks ajaks veel t-täheni jõudnud. Vene entsüklopeediast sain teada, et tegemist on paleoasiaatidega ja tšuktše on umbes 11000.

Tartu Ülikooli Raamatukogust laenutasin Vladimir Bogoraz-Tani raamatu Чукчи (Tšuktšid), aga tegelikult ei jõudnud sellega tutvuda. Lugesin nii palju, kui aega oli, ja aru sain, sest raamat oli venekeelne. Ma ei olnud veel teeninud Nõukogude armees, keskkoolis õpitud vene keelest jäi väheseks ja mul oli raskusi arusaamisega.

Meelde jäi üks V. Bogoraz-Tani tähelepanek:

Tšuktše ei saa nimetada meie tsivilisatsiooni vaatepunktist korralikeks inimesteks. Nad söövad omaenda täisid, pesevad kusega ja lasevad koertel oma kausid puhtaks lakkuda. Nad tarvitavad söögiks põhjapõtrade kiinide vastseid. Karjused

http://haldjas.folklore.eeltagused/nr31/ylojaht.pdf 


\section{Ülo Siimets}

söövad vahel põhjapõtrade väljaheiteid segatuna mitmesuguste noorte taimede roheliste vorrsetega. Kuid neil on omad arusaamad korralikkusest. Nad vaatavad vastikusega lehmapiima, sest peavad lehma räpaseks loomaks. Nad kinnitavad, et loomalihal on eriline ebameeldiv lõhn, mis sarnaneb lehmasõnnikule. Paljud neist keelduvad minemast majja, kus keeb loomaliha.

Teiselt poolt, kui tšuktšidele ütelda, et hülgelihal on ebameeldiv hais, siis nad omakorda vaidlevad vastu öeldes: "Hüljes on puhas. Ta peseb ennast pidevalt puhtas vees, aga teie sööte oma räpaste loomade liha” (Bogoraz-Tan 1934).

Samas raamatus oli ka kirjas, et Tšuktšimaa oli Tsaari-Venemaa ainukene tegelikult autonoomne piirkond, mis oli jäänud venelaste poolt lõplikult vallutamata. Vastavalt Venemaa seaduste kogu ühele paragrahvile nimetati Tšuktšimaad Русская не вполне покоренная территория (Venemaa mittetäielikult alistatud territoorium) ja seal kehtisid kohalikud seadused Nõukogude Liidu loomiseni. Tegelikult alistati rändkarjakasvatajad-tšuktšid alles 1949. aastal.

Punase raamatu puhul meenuvad eelkõige haruldased taimed ja loomad. Tegelikult on hävinud ja hävimisel ka paljud rahvad. 1989. aastal koostasid Margus Kolga jt Vene impeeriumi rahvaste punase raamatu (Kolga \& Tõnurist \& Vaba et al. 1993), millesse on kantud 85 Venemaal elavat rahvast, kelle arv on väiksem kui 30000 ja kes on oma põlisaladel jäänud vähemusse. Nende rahvaste hulka on arvatud ka tšuktšid. Kuuludes väljasuremisohus rahvaste hulka, on neil õigus küttida kõiki loomi, keda nad söögiks tarvitavad. Vähemalt nii nad ise rääkisid ja ka talitasid.

Tšuktšidel ei ole jumalaid. Nad on üks väheseid rahvaid, kes jäid Vene impeeriumis ristimata. Nende usundisse kuuluvad kõiksugused haldjaid ja pahad vaimud. Haldjate ja vaimudega suhtlejateks on peale šamaani veel teadjamehed, keda nimetatakse giulet-remkkõn. Selliseid teadjamehi on iga põhjapõdrakarjatajate rühma hulgas.

Kuidas teada saada, kas vaimud saadavad sulle õnne? Tšuktši jahimeestel oli veel 19. sajandi lõpus komme võtta jahile minnes oma maa piiril kannikad paljaks ja istuda maha. Kui paljastest kannikatest ja suguelunditest jäi selge jälg maha, võis oodata õnnelikku jahti. Kui jälge maha ei jäänud, tuli hakata uuesti ohver- 
Ülo Siimets

dama, et ketljasid (tšuktši keeles 'pahad vaimud') armulikumaks muuta.

\section{Tšuktšide jahipidamisvahendid}

Vanasti oli tšuktšidel vähe püsse ja püünisraudu ning nad kasutasid palju vibusid, odasid ja muid püügivahendeid. Mitmed tšuktšid kasutavad arhailisi püügiriistu veel tänapäevalgi, aga seda põhiliselt sisemaal - karjakasvatajate juures.

Üheks selliseks püügiriistaks on uljuk - vastukaaluga silmus, mis asetatakse uru ette või pannakse jääst urupikendusse. Kui loom puudutab peibutiseks jäetud sööta, pääseb lahti vastukaal ja silmus kägistab ta. Nii püütakse karusloomi, eriti rebaseid ja polaarrebaseid. Põhimõtteliselt sama tüüpi püügiriistad, ainult vastukaalu asemel vedruga, olid kasutusel ka eestlastel. Mitmed sellised on tallel Eesti Rahva Muuseumi kogudes. Tüüpilised olid näiteks mitme püünisauguga hiirelõksud.

Väga teravmeelne lõks oli evkeev. Sissepoole kaldu seintega maa sisse kaevatud auk, mille siseküljed pritsiti veega märjaks, nii et moodustus jäine libe sein. Augule oli kaaneks pandud pöördlaud selle külge kinnitatud külmutatud lihaga. Kui loom hakkas liha haarama, pööras laud ennast ümber telje ja loom kukkus auku. Raskusest vabanenud laud pööras ennast aga vanasse asendisse tagasi ja lõks oli uuesti töökorras.

Püünisraudadega püüdmisel seoti rauad ketiga põõsa külge. Kui jaht toimus avamaal, kraabiti lume sisse sügav piklik auk. Sinna asetati puutoigas. Auk aeti lund täis ja sõtkuti tugevasti kinni. Toika külge oli kinnitatud kett, mis omakorda lõppes püünise küljes. Kui loom jäi lõksu, ei saanud ta lõksu kaasa viia.

Lindude küttimiseks kasutati eplökötjet. See rihmade küljes olevate kuulidega jahipüügivahend visatakse õhku - sellega püütakse linde lennult. Kuulidega rihmad seovad tabamisel linnu tiivad ja lind kukub alla. Jahimehel tuleb ta ainult üles korjata. Kasutati ka mitmesuguseid silmuseid.

Karujahil käidi lühikese odaga veel 20. sajandi keskel. Oda pikkus ei tohtinud olla üle 1,5 meetri, et karu ei saaks oda puruks murda. Kohtusin kahe vana tšuktši jahimehega, kes olid nooruses jahiodaga mitmeid karusid tapnud. Vanaduses eelistasid nad siiski püssi. Jahimees Uttel olevat oma elus tapnud 52 karu. 


\section{Ülo Siimets}

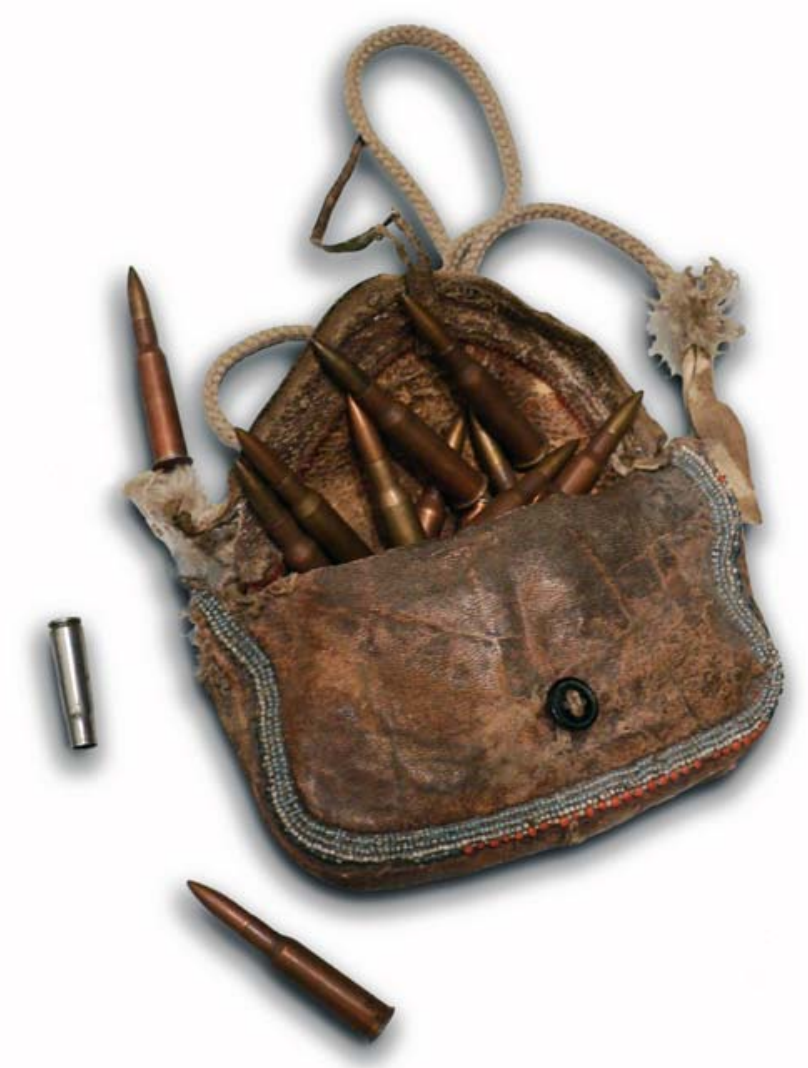

Joonis 1. Hülgenahast padrunikott. Andres Kuperjanovi foto.

Räägiti ka karu püüdmisest trossist silmuse abil. Selleks tehti palkidest püsttaraaedik, millesse jäeti meetrilaiune avaus. Avausse looma pea liikumise kõrgusele asetati terastrossist silmus, mis seoti puu külge. Aedikusse pandi tünn roiskunud kalaga. Kalahaisu peale kohale tulnud karu sattus aedikusse sisenemisel silmusesse. Hakates rabelema ja jõuga terastrossi sikutama, lämmatas loom enda. Sellist püügivahendit ma oma silmaga ei näinud, aga sellest rääkisid Vene piirivalvurid, kes seda püügiviisi kasutasid. 
Ülo Siimets

Tänapäeval kasutatakse põhiliselt Vene püsse ja lisaks muidugi tehases valmistatud püünisraudu ja lõkspuure.

\section{Jahiloomad ja -linnud}

Rannaäärsed tšuktšid tegelevad põhiliselt mereloomade küttimisega. Põhilised jahiloomad on morsad (Odobenus rosmanus), habehülged (Erignathus barbatus), randalid (Phoca vitulina), viigrid (Phoca hispida), vaalalised (Cetacea). Vene televisiooni andmetel annavadki 60 protsenti Tšukotka jahimajanduse toodangust vaalalised.

Talvel püütakse ka jäneseid (Lepus timidus), rebaseid (Vulpes vulpes), polaarrebaseid (Alopex lagopus), ahme (Gulo gulo), hunte (Canis lupus) ja vahel ka jääkarusid (Ursus maritimus).

Karjakasvatajad-tšuktšid elavad sisemaal. Nende jahiloomad on põdrad (Alces alces), metsikud põhjapõdrad (Rangifer tarandus), lumelambad (Ovis canadensis), pruunkarud (Ursus arctos), vahel harva jääkarud (Ursus maritimus) ning muidugi ka jänesed, rebased, hundid, ahmid.

Jahindusele spetsialiseerunud tšuktšid püüavad kõiki eespool nimetatud maismaaloomi, lisaks veel harilikku oravat (Sciurus vulgaris), harvem metsnugist (Martes martes) ja soobleid (Martes zibellina). Soobleid ja nugiseid püütakse põhiliselt Tšukotka lõunaosas.

\section{Karujaht koopasuul}

Jõudsime Tšukotkale 11. jaanuaril ja meie esimene jaht oli pruunkarujaht. See oli õnnelik juhus. Kui läksime kolhoosiesimees Kanõgini käest tööd küsima, saabus sinna tundrast tšuktšist jahimees Uttel. Et olime kaugelt tulnud külalised ja meid oli kutsunud Tšukotkale Utteli oma tütar, õnnestus esimehel keelitada vana jahimeest karukoobast näitama. Kolhoosiesimees võttis meid kaasa. Jahi põnevaimaks osaks kujunes kohtumine kohalikega, kes rääkisid jahilugusid.

Et olen sellel teemal juba varem kirjutanud, siis ei hakka ma seda jahilkäiku pikalt kirjeldama. Karukoobas oli Vaegi külast ligi 80 kilomeetri kaugusel. Uttel tegi koopalumme avause, kuhu aeti 


\section{Ülo Siimets}

jahilaika. Karu tormas koopast välja ja lasti maha. Karunahk sai kolhoosiesimehele, liha jagati külaelanike vahel. Kuna olime võõrad ehk tangid, siis meil karupeietest osa võtta ei lubatud (pikemalt vt Siimets 2000: 133-156).

20. sajandi teisel kümnendil viibis Johannes Niggol mitmed aastad põhiliselt Kamtšatkal, aga tegi reise ka Tšukotkale. J. Niggoli teekond viis ta ka Markovosse, mis asub $300 \mathrm{~km}$ kaugusel Vaegi külast, kus elasin 1971. aastal, kuid tema ajal ei olnud Vaegi küla veel olemas. Ta kirjutab oma raamatus Matkapilte Kamtšatkalt järgmist:

Anadõrist Lopotkani elab pruunkaru, ja mida lõuna poole, seda rohkem neid leidub. Ta on vist karudest kõige arglikum ja heasüdamlikum, keda väga palju ei karda ka marjul käivad külanaised. Neid kütitakse enne talveuinakut, sest siis on nad rikkalikust ja kergesti saadavast kalatoidust endale naha alla kogunud tubli rasvakorra. Mägedes, kõiksugu rusu alla jääb ta talveunne ja ta hingeaur värvib kollakaks ta koopale sattunud lume. Selle koha märgib ära sooblikütt, kes ilmub kevadel kergetel suuskadel, kui lumi on pehme ja karul kiire kõndimine võimatu. Nü̈̈d ajab kütt karu koopast välja ja laseb kerge vaevaga maha. Juhtub, et ühte koopasse jääb uinakut pidama mitu karu või suurem karude pere. 1921. a. kevadel laskis keegi Natšiki küla elanik selle küla ligidal mõne minuti jooksul seitse karu, keda ta koerte abil koopast välja ajas. Karuliha ja rasv maitsevad väga hästi (Niggol 1937: 54).

Kui kamtšadaalid, tšuktšid ja korjakid jahtisid karu igal sobival võimalusel, siis Niznõi Kolõmi lähedal elavatele eveenidele oli karujaht peaaegu keelatud. Boris Kartašovi andmetel oli karu neil peaaegu looduskaitse all olev loom. Ta kirjutab:

Ainult siis, kui nälg perekonda väga tugevalt kägistas ja nende elu oli ohus, kui tulevikus ei paistnud mitte mingit võimalust ega lootust leida muid elatusvahendeid, otsustas eveen minna karujahile. Ebausklik hirm karu ees oli nii tugev, et tavalise jahi ajal ei julgenud eveen vaadata isegi maha jäänud karujälgedele.

Karujahti alustati rituaalsete laulude ja keeruliste rituaalidega. Pärast edukat jahti pidi eveenist kütt tervitama karu 
Ülo Siimets

ja tänama selle eest, et karu ei keeldunud tulemast. Karuliha ei tohtinud jätta tagavarana varuks. Kui üks perekond ei suutnud korraga tervet karu ära sü̈̈a, kutsuti appi naabrid. Naistel oli lubatud visata karuliha ka koertele toiduks. Pärast pidusööki korjasid eveenid kondid kokku, sidusid nendest kokku skeleti ja panid lavatsile. Nende rituaalid olid seotud iidse totemismiga ajast, kui ürginimene uskus oma hõimu veresugulust mingi kindla elusolendi - tootemiga. Sellisesse looma suhtusid nad mitte nagu jumalasse, vaid kui esivanemasse, kui isasse või vanemasse venda, kui sugulasse-kaitsjasse (Kartašov 1959: 24-25).

Ka minu kogemuste järgi ei lubatud karuliha üksi süüa, vaid seda tuli jagada oma sugulaste peredega. Tšuktšid pidasid karusid oma metsarahvaks (Siimets 2000: 133-156).

Jaanuaris, veebruaris, märtsis käisime kalal ning jahtisime jäneseid, oravaid ja rabapüüsid (Lagopus lagopus). Rabapüü- ja jänesejaht oli talvel põhiline värske liha saamise viis. Rabapüüjahile mindi suuskadega jõejääl piki jõge liikudes jälgiti kaldaäärseid puid ja põõsaid. Rabakanad olid nagu valged lumepallid puude otsas. Laskmist tuli alustada alumistest lindudest. Spordipüssi lasule linnud eriti ei reageerinud. Kui alumine lind alla kukkus, vaatasid nad uudistades ülevalt alla, miks üks lind maas sipleb. Jahipüssi pauk hirmutas aga loomulikult kogu parve õhku. Linnujahilised järgnesid suuskadel linnuparvele. Nii kestis jaht terve päeva.

Jäneseid püüdsime jooksuradadele asetatud lõksude ja silmustega. Erilist saaki me ei saanud, sest panime püünised liialt küla lähedale ja aeg-ajalt oli keegi neid

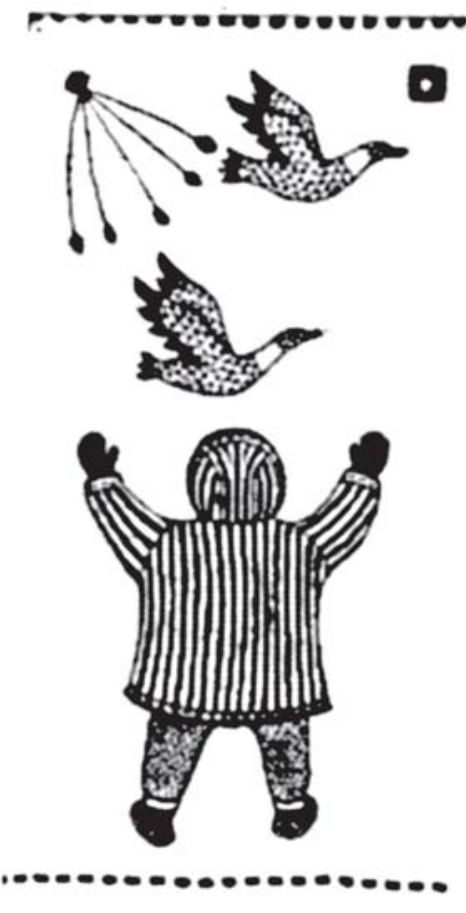

Joonis 2. Linnujaht eplökötjega (Andrejeva \& Gorbatšova 1990). 


\section{Ülo Siimets}

tühjendanud. Tšukšid süüdistasid sellistes pahategudes tạge muulasi -, kel ei ole mingit autunnet võõraste püüniste ees.

Huvitav on see, et metsavööndis teevad jänesed ainult suurte külmade korral lumme 0,5-1,5 m pikkuse koopa. Hädaohu korral põgeneb loom magamispaigast. Teistmoodi on lugu Tšukotka tundras, kus jänesed koonduvad talvel kohtadesse, kus on palju lund, harilikult jõgede järskudele nõlvadele. Nad kaevavad sügavaid kuni 10 meetri pikkusi käike. Sealt on neid kätte saada peaaegu võimatu, sest nad ei hülga pelgupaika püssipaukude, kisa ega lumel trampimise peale. Suvel kasutavad valgejänesed ümisejate koopaid, mis on kaevatud igikeltsa sisse.

Kord jälitasime kahekesi suuskadel väikest metsikute põhjapõtrade karja, aga nende lähedale jahipüssi laskekaugusse ei õnnestunudki pääseda.

\section{Hanejaht}

Aprilli lõpul rentisime kuuekesi lennuki AN 2 ja meid viidi külast umbes 300 kilomeetri kaugusel põhja pool asuvasse tundrasse. Lennuk pidi meile järele tulema kolme päeva pärast. Ilm oli pehme, lumi sula. Maandumiskoha lähedal oli mäekuru. Üle kuru põhja poole lendas iga päev kümneid või isegi sadu linnuparvi. Panime laagri üles Anadõri lisajõe kaldale. Esimesel päeval oli mägedes lumetorm ja linnud ei lennanud. Tšuktši jahimees Maksim, umbes 50-aastane mees, õpetas meile, millist häält tuleb hanede petmiseks läbi peopesade puhudes teha. Harjutasime ajaviiteks hanede häälitsusi. Teisel päeval hakkasid meist üle, lõunast põhja suunas, lendama haneparved. Igas parves oli 30-50 lindu ja parved tulid üle mägede mõneminutiliste intervallidega. Mehed hargnesid mööda jõeorgu laiali.

Peitusime lumest paljaks sulanud jõkke ulatuvatel liivaribadel (vene keeles ' $\mathrm{Koca}$ '). Sellistesse kohtadesse olid kuhjunud kusagilt jõe kaldast koos juurtega alla varisenud puude ja põõsaste kuhilad, mis andsid hea peitumisvõimaluse. Hakkasin õpetatud viisil häälitsema. Haneparv pikeeris ülevalt alla. Mul oli 12-kaliibriline kaheraudne Vene püss TOZ 66. Tulistasin, kuid tulemusteta. Haneparv hakkas kisama, tõusis kõrgemale ja lendas minema. Mingi aja jooksul ei tulnud haneparved lähemale. Siis saabusid üle mägede uued haneparved, kes lasid ennast ära petta. Tulistasin. Ei midagi. Nii 
kordus õhtuni. Päeva lõpuks olin lasknud ainult ühe hane. Teda oli tabanud juhuslik haavel silma. Tšuktš Maksimil oli üheraudne püss, kuid ta oli lasknud kuus hane. Teistel ei olnud ühtegi hane. Maksim õpetas meid, et ei tasu enne lasta, kui hanede jalad selgesti paistavad.

Õpetust järgides ei jäänud järgmisel päeval keegi saagita. Kõige vähem oli hanesid saanud 5-lasulise automaatpüssi MTs 21 omanik Vorobjov, kes oli lasknud ainult viis hane. Ta oli jahile kaasa võtnud 800 padrunit ja tulistanud nendest välja ligi pooled. Sellest oli tal õlg koguni valusaks jäänud. Tulemus oli nigel - keskmine tabamisprotsent 80 lasust üks või veelgi vähem. Jutuajamisest selgus, et ta ei olnud kuulanud Maksimi õpetust ja lasi linde liiga kaugelt.

Mina sain tookord 11 hane. Maksim sai kõige rohkem - 26 hane. Traktorist Sanja oli lisaks 8 hanele lasknud ühe laululuige (Cygnus cygnus). Ta nülgis luigelt naha maha ja soolas sisse. Lubas naha Moskva Suure Teatri baleriinidele müüa, need maksvat luigenahast boa eest hingehinda. Mina ei osanud selle kohta midagi arvata. Luigeliha küpsetasime lõkke peal. Lind oli vana ja liha sitke. Kohalikud teadsid rääkida, et Inglise kuninganna pidi igal aastal jõuludeks sööma luigepraadi. Vähemalt olevat see nii olnud enne luikede looduskaitse alla võtmist.

Ei kujuta ette, kui kaua pidid kokad luike küpsetama, enne kui ta Inglise kuninganna lauale pandi.

Järgmisel päeval pidi lennuk meile järele tulema, kuid ei saabunud. Pärastlõunal algas lumetorm ja ilm läks külmaks. Torm kestis kolm päeva. Õnneks olid meil kaasas talvised paksust põhja-

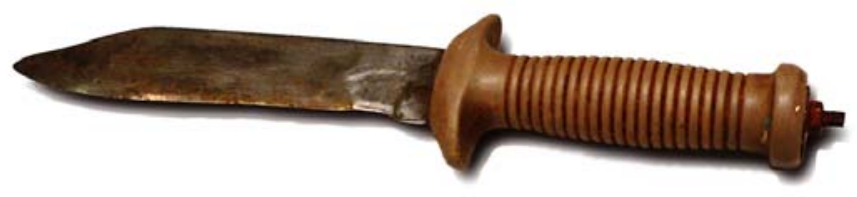

Joonis 3. Ülo Siimetsa jahinuga. Andres Kuperjanovi foto. 


\section{Ülo Siimets}

põdranahast magamiskotid kukulid, milles kohalike jutu järgi võis magada lumehanges isegi 40-kraadise pakasega. Külma oli päeval aga ainult umbes 10 kraadi ja öösiti langes temperatuur 1520 külmapügalani. Lumetorm vaibus, aga lennukit ei tulnud. Ilm muutus jälle soojaks ja lumi hakkas sulama. Toit ja tubakas olid otsa lõppenud. Ootasime veel päeva ja hakkasime suuskadel kodu poole liikuma. Enne minekut kaevas Maksim noa ja luulusika abil ühe puu juurde igikeltsa sisse augu, kuhu pani kilekotiga 20 lindu. Ta ajas mulla peale tagasi ja veeretas suured kivid oma linnulao kohale. Mees ütles ise, et linnud laagerdavad maa sees ja neile on paras kuu aja pärast, kui vesi jões tõuseb, paadiga järele tulla. Ka mehed, kel oli kaasas liigselt laskemoona, panid padrunid kotti ja sidusid koti puu otsa, et loomad neid kätte ei saaks. Pärast selgus, et see ei olnud aidanud. Karud olid roninud puu otsa, kotid alla tirinud ja puruks rebinud ning vihm oli rikkunud laskemoona.

Oli algamas polaarpäev ja päike peaaegu ei loojunudki. Päeval muutus lumi kohevaks ja seetõttu oli raske liikuda. Suusad vajusid sügavale lume sisse. Liikusime edasi öösiti, kui temperatuur oli alla nulli. Toiduks tarvitasime lastud linde. Vanemad mehed väsisid ära ja hakkasid oma seljakotte tühjendama, visates aegajalt mõne hane maha. Seetõttu oli meil hanerada taga. Nende lõhn meelitas juurde ümbruskonna karusid. Mõned julgemad tulid laskekaugusesse, aga et polnud teada, millal saabub lennuk, ei tulistanud neid keegi - rasket nahka ei tahtnud keegi kaasa lohistada.

Ühe puhkepausi ajal läks Vorobjov kääbusseedermänni põõsastiku taha "kõhtu kergendama". Mõne aja pärast hakkas kostma hirm-

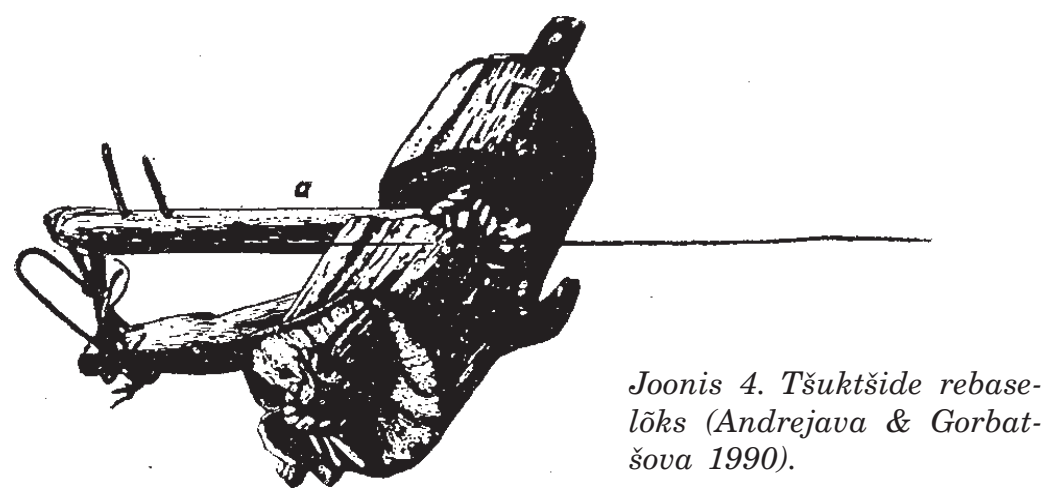

wrww.folkLore.ee/tagused 168 
sat karjumist. Põõsa tagant tormas välja Vorobjov, kes karjus ühe käega pükse üleval hoides: "Karu tuleb!" Mehed kargasid püsti ja haarasid püssid kätte. Vorobjov jooksis meieni - karu ei kuskil. Püksirihma kinnitades seletas mees, et karu tormanud tema peale, kui ta põõsa taga kükitas. Hiilisime, püssid käes karu suunas. Põõsa taga karu enam polnud, kuid hunnikust paari meetri kaugusel olid tõesti karujäljed. Vorobjovi kisa peale oli karu minema jooksnud. Pöördusime laagrisse tagasi.

Kaheksapäevase rännaku järel jõudis lennuk meile järele. Olime jõudnud juba üsna küla lähedale. Poole tunni pärast maandusime Vaegis.

\section{Ulukpõhjapõdrajaht}

Mai keskel võeti meid sõbraga praamile madrusteks. Käisime Maeni ja Anadõri jõe ristumiskohas puidu järel. Seal lähedal oli metsikute põhjapõtrade ülerändekoht. Nagu jutustas meile laeva kapten Innokenti, on seal aastasadu jahil käidud, sest ulukpõhjapõdrad käivad pidevalt mõõda ühtesid ja samu radu.

Ferdinand Wrangel kirjutab oma raamatus Путешествие по северным берегам Сибири и по Ледовитому морю (Reis mööda Siberi põhjarannikut ja Põhja-Jäämerel):

Õnnelikel aastatel kü̈̈nib põtrade arv mitme tuhandeni ja nad liiguvad 50-100 versta pikkuse voorina. Tegelikult on karjad väiksemad, 200-300-pealised, kuid nad astuvad nii üksteise kannul, et sulavad kokku hiigelkarjaks. Rännutee on neil alati sama - antud juhul Kuiva Anjui ja Plotbištši vahel. Suure vee ületamiseks laskuvad põdrad mööda endist voolusängi või madalaks ahkunud ja kuivaks jäänud väiksemat harujõge suure jõe orgu, valides sellise koha, kus vastaskallas on lauge. Algul koguneb kari tihedasse summa, seejärel astuvad juhtpõder ja paar tugevamat kaaslast mõned sammud vee poole, tõstavad pea kõrgele ja uurivad ümbrust. Veendunud, et hädaohtu ei ole, sööstavad juhid vette. Neile järgneb kogu kari ja paari minuti pärast on jõgi ujuvaid põtru pilgeni täis. Kütid, kes seni varjusid paatidega kivide ja põõsastiku taha, harilikult allatuult, tormavad nü̈̈d neile kallale, piiravad põdrad sisse ja pü̈avad neid kinni pidada. Paar-kolm kõige ko- 


\section{Ülo Siimets}

genumat kütti, relvastatud pikkade piikide ja torkeriistadega, tungivad karja keskele ja asuvad ujuvaid põtru uskumatu väledusega nottima. Harilikult piisab ühest löögist, et loom tappa või teda nii raskelt haavata, et ta vaevu jaksab vastaskaldani ujuda.

Põtrade veristamine on ohtlik töö. Küttide tilluke paat ähvardab iga hetk puruneda või kummuli pöörduda selles tihedas, korrapäratus melus, kus põdrad end igati kaitsta pü̈avad. Isased hammustavad, puksivad sarvedega, löövad takka üles, emased pü̈̈avad esijalgadega paati karata ja sõidukit uputada või kummuli keerata. Kui neil õnnestub paat ümber ajada, on küti surm peaaegu kindel. Ta võib veel eluga pääseda, kui ta mõnest tugevast ja haavamata põdrast kinni haarab, kes ta kaldale veab. Onnetusi juhtub siiski üsna harva, sest kütid on uskumatult osavad paati juhtima, tasakaalus hoidma ja loomade kallaletunge tõrjuma. Kogenud kütt tapab vähem kui poole tunniga sada või enam põtra. Kui kari on suur ja satub paanikasse, on tapmine mugavam ja ohutum. Ülejäänud jahimehed pü̈̈avad ujuvad loomakorjused kinni ja seovad rihmadega paadi külge (Wrangel 1948: 221222).

Sisemaalt, peamiselt Anadõri jõe kallastelt leitud kiviriistad lubavad järeldada, et F. Wrangeli kirjelduse sarnaselt on metsikuid põhjapõtru Tšuktšimaal kütitud kolm kuni neli tuhat aastat. Koolmetel varitsemisest arenes aja jooksul põhjapõtrade piiramine ja põhjapõdrakasvatus. Kodustatud põhjapõder erineb metsikust põhjapõdrast juba morfoloogiliselt: viimane on suurem. Karjainstinkt esineb metsikul põhjapõdral ainult hooajalise rände ajal, kodustatud põhjapõdral alati. See osutab põdrakasvatuse pikale arenguloole. Tšuktšimaal on praegu pool miljonit põhjapõtra. Otseselt on nendega seotud veidi alla kahe tuhande inimese. Koolis õppisime, et Eestis kütiti põhjapõtru viimati Kunda kultuuri algpäevil.

Õhtuks jõudsime koolmekohta, kus põhjapõdrad jõge ületavad. Praam jäi kalda äärde ankrusse. Panime sisse kalavõrgud, võtsime püssid ja läksime otsima metsikuid põhjapõtru. Kaldapervele ülesse tõusnud, selgus, et nii kaugele, kui silm ulatus, oli tundra kaetud veega. Kaldaäär oli ümbruskonna kõrgeim koht. Kõndisime mööda seda, kuni leidsimegi põtrade ülekäiguraja, mis 
oli mudale tambitud. Põhjapõtru ei olnud mitte kusagil näha. Olime suurele jahile hilinenud. Kari oli juba üle jõe põhja poole läinud. Sumasime läbi vee kaugemal asuvate sopkade poole. Kohati oli vesi peaaegu üle põlve, ulatudes pikkade kalamehekummikute servani. Siis läks vesi veelgi sügavamaks ja me pöörasime praami juurde tagasi. Ei näinud me ühtegi põhjapõtra, laskmisest rääkimata.

Hiljem kirjandusest leidsin andmeid, et 20. sajandi alguseks olid suured ulukpõhjapõdrakarjad peaaegu hävitatud. Pärast metsiku põhjapõdra looduskaitse alla võtmist hakkasid nende karjad aeglaselt suurenema ja 20. sajandi teisel poolel oli kohati lubatud limiteeritud ulukpõhjapõdrajaht.

Põhjapõdrakarjas olles õnnestus mul

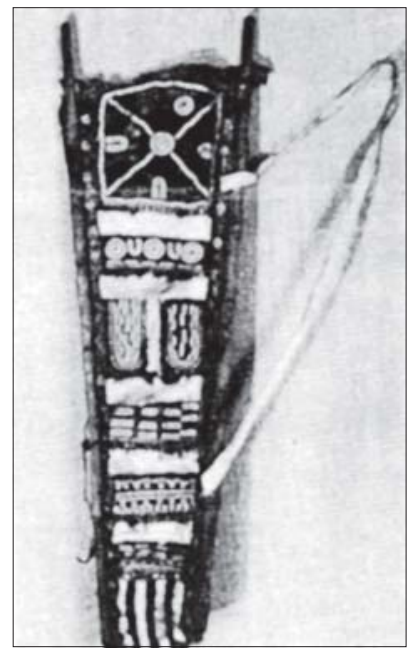

Joonis 5. Tšuktšide noolekott (Andrejava \& Gorbatšova 1990). septembris üks karja hulka tulnud metsik põhjapõder maha lasta. Ta oli kodustatud põhjapõtradest veerandi selja võrra pikem. Tema sarved olid tunduvalt suuremad kui meie karja pullidel. Mul õnnestus tabada teda vintpüssist kaela, kui ta üle karja meie suunas vahtis. Kahjuks jäid trofeesarved tundrasse, sest seda kraami, mida seljas tuli kanda, oli liiga palju.

Hommikul tõmbasime võrgu välja. Seal oli rohkesti mitmesuguseid kalu, kõige suurem ligi 25-kilone nelma. Tema tegelikku kaalu ma ei tea, aga meeste jutu järgi kaalus ta umbes veerandsada kilo. Kui kala püsti tõstsime ja sabaotsa vastu maad toetasime, ulatus see tšuktš Maksimile peaaegu lõuani.

\section{Veel metsikutest põhjapõtradest}

Innokenti teadis rääkida, et maailmas elab umbes kaks miljonit metsikut põhjapõtra, enamik neist Põhja-Ameerikas. Ameerikas kutsutakse neid karibuudeks. Nõukogude Liidus olevat ligi 800000 metsikut põhjapõtra. Minevikus oli neid loomi mitmeid kordi rohkem. Põhjarahvastel polnud vajadust põhjapõtru kasvatada, sest neid 


\section{Ülo Siimets}

olid kõik tundrad paksult täis. Varem ei olnud Ameerikas üldse kodustatud põhjapõtru ja indiaanlased elatusid karibuude küttimisest. (Karibuu on tuletatud indiaanikeelsest sõnast tseribuu ja tähendab 'need, kes lume alt toitu kraabivad.') Emaseid karibuusid kutsuti kulavak, mis tähendab 'need, kes on jõudnud poegimise ikka'.) Kodustatud põhjapõdrad viidi Ameerikasse 19. sajandi lõpul.

Metsikud põhjapõdrad eelistavad künklikku maastikku orgude ja järvedega. Sellistes kohtades kasvab palju rohttaimi. Nad rändavad pidevalt sõltuvalt aastaajast põhjast lõunasse ja lõunast põhja.

Talvel ollakse metsatundras, kus lumekiht on natukene õhem ja toit kättesaadavam. Laiad sõrad lasevad põhjapõtradel lume peal joosta, nende teravad kausitaolised otsad lasevad kaevata lumme sügavaid auke, et sammalt kätte saada. Suvel lähevad nad sitikate eest põhjapoolsetesse mägedesse, kus tugevam tuul peletab putukad eemale. Tšuktšimaa päris põhjapoolses osas liiguvad põdrakarjad peaaegu mereni välja. Põdrakarjad liiguvad põhjast lõunasse ja tagasi ligi tuhat kilomeetrit. Ränded sõltuvad lumikatte sügavusest, toitumismaade olukorrast, loomade arvukusest. Ühe karja rände üldsuund, käigurajad ja jõeületamiskohad on alati samad. Seda kasutavadki ära jahimehed, kes jäävad mõne jõesängi lähedusse varitsema. Lõunapoolsesse metsatundrasse hakkavad karjad liikuma septembris, tagasi tundrasse tullakse mais, läbides taas kuuga tuhat kilomeetrit. Kõige enne saabuvad tundrasse tagasi tiined emased. Juba aprillis peavad nad alustama rännakut, sest nad peavad jõudma üle mäeahelike enne poegimise algust. Mägedes on siis veel külm. Toitu on vähe, aga tiined loomad ruttavad aina edasi. Teel on ees palju jõgesid. Vahel jõutakse üle suurte jõgede juba siis, kui need on veel jääs ja seetõttu kerged ületada. Nad leiavad jõe peal instinktiivselt paksema jääga koha.

Tihti on üleminekuajal jõgedel juba jääminek. Jäätükid hulbivad vees nii tihedalt, et neile ei jää peaaegu üldse vahet. Kõige ees laskub vette juhtemane. Tema järel sööstavad teised emased põhjapõdrad vette. Sajad loomad lähevad vette üksteise järel. Vesi on külm, ainult üks-kaks kraadi üle nulli. Inimene külmuks sellises vees mõne minutiga. Emastele põhjapõtradel on vettemineku sunniks ürginstinkt - jõuda enne poegimist toidurikkasse tundrasse. Mõned põhjapõdrad ronivad vees hulpivatele jääpankadele puhkama ja vesi viib neid allavoolu tundmatusse. Kui jääpank satub vastu kallast, pääsevad nad üle jõe. Kui jääpank tormab vastu jäämurdu, hukkuvad nad jäätükkide vahel. Karud ootavad jõe kaldal, et püüda noori loomi. 
Ulukpõhjapõdrad näevad halvasti, aga tunnevad hästi lõhna. Samuti kuulevad nad hästi. Tugeva sideme emaga tagab vasika hääl, mida kuuldes ema jookseb vasikale appi. Kuid ka karu kuuleb häält ja kui ta jõuab kohale esimesena, ei ole enam midagi päästa. Ilma emata ei ole väikesel põhjapõdral võimalust ellu jääda. Kuid ühtede hukkumine on looduseaduste järgi kasulik teistele.

Isased ja ahtrad emased hakkavad liikuma hiljem, kui põhikari on lahkunud.

Emased hakkavad poegima lagedas tundras. Vasikas ripub tagant välja, põhjapõder keerutab ja vasikas kukub maha. Ema närib nabanööri läbi, lakub poja puhtaks ja heidab poja kõrvale maha. Mõne minuti pärast rabeleb vasikas jalule ja sellest hetkest saab poeginud põhjapõdrast hoolitsev ema. Poeg suudab paar tundi pärast sündimist emaga sammu pidada. Kui sündides kaalub vasikas kaks-kolm kilo, siis paari nädalaga kasvab kaal kahekordseks.

Mõned vasikad sünnivad hiljem. Isegi paar päeva varem sündimine on tähtis ja maksab tihti elu.

Ulukpõhjapõdrapullid elavad looduses 12-aastaseks ja emasloomad 15-aastaseks. Nende peamine looduslik vaenlane on hunt, kes rünnates haarab põhjapõdra tagajalast kinni, samal ajal kui teine hunt tormab appi, haarates põdral kõrist kinni, ja ongi loomast saanud huntide saak. Nirk sööb korjust altpoolt, hunt ülevalt. Üks põhjapõder päästab hundi ja nirgi näljast paariks nädalaks.

Juuni algul puhkeb tundra õide ja põhjapõdravasikad kasvavad jõudsalt. Juuni lõpuks on kõikjalt lumi sulanud peale üksikute laikude mäetippudel. Tundra on täis rammusaid taimi ja rabakanad jõudnud saada suvise sulestiku.

Juuni lõpul ja juuli alguses piinavad põhjapõtru miljonid sääsed. Loomadele kasvavad nahaga kaetud sarved, millel istuvad verd imevad sääsed. Kiinid ründavad jalgu, ninakiinid püüavad pääseda ninna.

Juulis jõuavad isased põhjapõdrad karjale järele. Kaitseks putukate vastu surutakse end kokku. Ümber karja südamiku tormavad põhjapõdrad, et parme ja kihulasi maha raputada. Sääski on nii palju, et suvel kaotab põhjapõder umbes liitri verd nädalas. Sääskede tõttu ronivad ulukpõhjapõdrad mägedesse toituma - seal on tuulisem ja putukaid vähem, kuid ega nad sealgi kaitstud ole. Loomad kogunevad jää-ja lumelaikutele mägede lääne- ja põhjaküljes, sest sääsed ei taha külmale lumele tulla.

Toitu on tundras külluslikult. Vaatevälja piiravas pajuvõsas varitsevad põhjapõtru karud - avamaastikul on neil raske neid kätte 


\section{Ülo Siimets}

saada. Augusti alguses hakkavad isased põhjapõdrad sarvi nahast vabastama. Sarved langevad neil maha detsembris.

Kuuenädalased vasikad on jõudsalt kasvanud.

Esimesed külmad augusti lõpul hävitavad viimased putukad. Nüüd on põhjapõtradel rahulikum. Sarvede kasvamine vähendab täiskasvanud põhjapõtrade jõuvarusid. Septembris söövad põhjapõdrad vahetpidamata. Nad on ennast täis nuumanud ja loivavad laisalt tundras ringi. Nüüd on isegi üksik hunt võimeline ulukpõhjapõdra kinni püüdma.

Toitumiseks on aga vähe aega, sest enne tormide algust tuleb alustada tagasiteed lõunasse, et pääseda üle mägede. Ees ootab neid $1200 \mathrm{~km}$ pikkune teekond, samad jõed, kust nad lõuna poole rännates üle tulid, karud ja muud ohud.

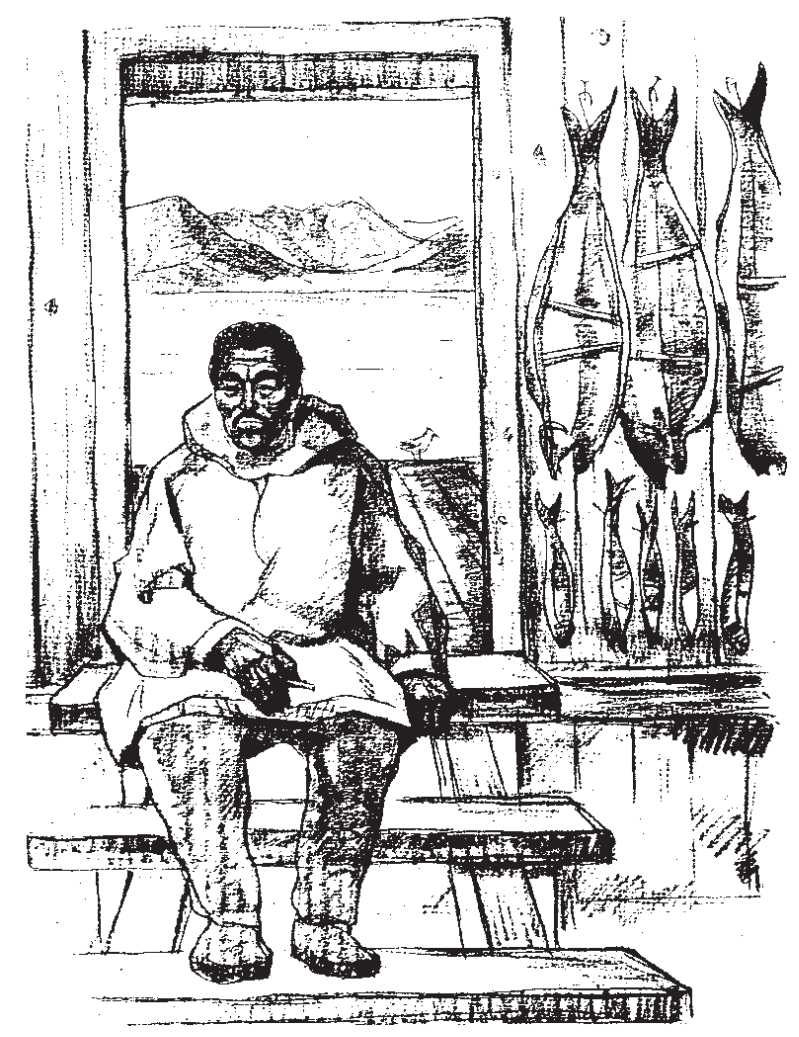

Joonis 6. Třuktši kalur puhkehetkel (Andrejava \& Gorbatšova 1990). 


\section{Jääkarujaht ja lumelambajaht}

Olen kirjutanud varasemas artiklis jääkarujahist ega korda seda siin uuesti (Siimets 2003: 162-167). Jahil haavatud looma jälitasin veriseid jälgi mööda sopkadel, kuid tulistamiseks oli vahemaa liiga suur. Tormasin põõsaste vahelt karule järele. Mäest allaminek läks kiiresti, kuid järgmise sopka otsa jõudmine oli järsu tõusu tõttu raske ja hakkas juba hämarduma.

Kui ma lõpuks sopka otsa jõudsin ja silmadega looma otsisin, oli juba üsna pime. Ma ei näinud kusagil karu ja otsustasin hommikul varavalges teda otsima tulla. Laskusin sopkalt orgu. Seal toimus rituaalne paha vaimu tõrjumine (Siimets 2003: 20).

Järgmisel päeval mind jahile ei lubatud, sest tšuktšidel on keelatud haavatud looma jälitamine. Kui esimese korraga looma ei saadud, siis paha vaim ei tahtnud, et see kätte saadakse. Käsku eirates võid kõikidest loomadest suu puhtaks pühkida.

Maailmarändur Otto von Kotzebue raamatus Reis ümber maailma aastail 1823-1826 on kirjas:

Kohaliku päritoluga metsik lammas elab kõige kõrgematel mäetippudel. Kasvu poolest on ta nagu suur kits, pea on tal nagu harilikul lambal, kuid ainult suurte sarvedega, mis allapoole pööratud on. Keha ja karvkate sarnanevad täiesti põhjapõdra omadega, kellega ta sööb ka sama toitu - sammalt. Ta on kiire ja väle ning teeb tohutuid hüppeid üle kuristike nagu mägikits, mistôttu on teda raske tabada. Kui ta ühelt kaljutipult teisele hüppab, tõmbab ta kõik neli jäset kok$k u$, lendab pea ees ning põrkab sellega kõige esiti selle punkti vastu, kuhu ta minna tahtis. Alles siis võtab ta appi jalad. Silmamõõt, mille järgi ta hüppeks kasutatavat jõudu mä̈̈rab, on ikka väga õige. Tihti on paik, kuhu loom hüppab, vaid nii suur, et ta oma esi-ja tagajalad lähestikku asetama peab, et paigal seista, ning ometi ei hüppa ta kunagi märgist mööda. Sama imetlusväärne on see tasakaal, mille loom pärast hüpet kohe kätte saab. Meie balletitantsijad võiksid temast võtta eeskuju täielikuks enesekindluseks (Kotzebue 1978: 162 ).

Päris sellist pilti mul näha ei õnnestunud. Käisin mitmeid kordi tšuktšidega lumelambajahis. Tšuktšid õpetasid, et tuleb jahi ajal 
rahulikult kõndida ja mitte teha järske liigutusi. Kui lumelambad sind märkavad, ei tohi varjuda, vaid tuleb rahulikult minna vintpüssi laskekaugusse ja siis tulistada. Kui mööda lased, pead mitmeid tunde vantsima, et uut karja leida - seesama kari sind enam ligi ei lase. Karjasoleku aja jooksul onnnestus mul lasta kaks lumelammast.

Suuremad sarved kaalusid tšuktšide arvates 15 kilo või rohkem. Nendest suurtest sarvedest voolis tšuktši karjus suure luust lusika ja saatis Moskvasse NLKP XXIV kongressile ja Leonid Brežnevile, et meie isal oleks hea ühiskatlast süüa.

Need olid mõned huvitavamad hetked minu Tšuktšimaa jahilkäikudest.

\section{Kirjandus}

Andrejeva \& Gorbatšova $1990=$ Андреева, Л. В. \& Горбачева, В. В. (koost). Художественная обработка меха и кожи у народностей Крайнего Северо-Востока I: Чукчи. Эскимосы. Магадан: Магаданское книжное издательсво.

Bogoraz-Tan 1934 = Богораз-Тан, Владимир. Чукчи I. Ленинград: Издательство главсевморпути.

Kartašov 1959 = Карташев, Борис И. По стране оленных людей: Путешествия В. Г. Тана-Богораза. Замечательные географы и путешественники. Москва: Географгиз.

Kolga, Margus \& Tõnurist, Igor \& Vaba, Lembit \& Viikberg, Jüri (koost) 1993. Vene impeeriumi rahvaste punane raamat. Tallinn: Vagabund.

Kotzebue, Otto von 1978. Reis ümber maailma aastail 1823-1826. Kurvits, Ülo (tõlk). Maailma ja mõnda. Tallinn: Eesti Raamat.

Niggol, Johhanes 1937. Matkapilte Kamtšatkast. Tartu: Noor Eesti Kirjastus.

Siimets, Ülo 2000. Tšuktšid III. Mäetagused: Hüperajakiri 13, lk 133-156 (http://www.folklore.ee/tagused/nr13/tsukts.htm).

Siimets, Ülo 2003. Tšuktšid VII. Mäetagused: Hüperajakiri 20, lk 162167 (http://www.folklore.ee/tagused/nr20/jaakaru.pdf).

Wrangel 1948 = Врангель, Фердинанд П. Путешествие по северным берегам Сибири и по Ледовитому морю, совершенное в 1820, 1821, 1822, 1823 и 1824 гг. экспедицией по начальством флота лейтенанта Ф. П. Врангеля. Москва: Главсевморпуть. 